\title{
Ecology in Light of the Cape Town Commitment
}

\author{
Danijel Časni \\ The Biblical Institute, Zagreb \\ dcasni@bizg.hr
}

UDK: 502:277:27-27:2-44

Review paper

https://doi.org/10.32862/k.14.2.6

\begin{abstract}
The creation of the planet Earth together with the flora and fauna culminates with the process of creating man in the image of God. But that image man defiled with sin. This has resulted in the separation of creation from the Creator and the creation of various crises, including ecological crises. Accordingly, the topic of ecology is increasingly relevant in our time, and many representatives of the Protestant and Evangelical Christian Churches throughout history have spoken about the importance of ecology. In our time, that topic was discussed 2010. at the Third Lausanne Congress for the Evangelization of the World in Cape Town. Since the congress gathered a large number of representatives of evangelical churches around the world, the position presented in the form of a document is also a view of ecology from the prism of evangelical Christianity.
\end{abstract}

Since the love of God, among other things, is expressed in the love of God's creation, this article first analyzes the relationship between theology and ecology. After that, the discussion is about how the biblical record of creation should inform and shape the relationship of evangelical Christians toward the Earth. The third part of the article deals with the issue of "ecological footprint" at the world level but also looks at where is Croatia in all this. The fourth part of the article brings an overview of ecology from the prism of Protestant and evangelical churches, while the fifth part discusses the challenges of today and offers two directions: one is materialistic-humanistic, and the other is Protestant-evangelical. The article concludes that Christians as children of God are called to do the will of the Heavenly Father and to be the example and light in today's egocentric world. Ecological crises are directly 
correlated with the crisis of morality, but equally, all activities carried out to preserve the environment without changing human nature and consequently his habits, achieve only short-term results without fundamental changes. Only by changing man himself and his repentance can he become responsible in his ethical approach to the environment that surrounds him.

Keywords: creation, ecology, Earth, The Cape Town Commitment, evangelical Christianity

\section{Introduction}

The Old Testament book of Genesis gives us the account of the creation of the world. After the creation of the Universe, the planet Earth was created together with all the plant and animal life. The culmination of this process was seen in the creation of man, who was created in God's image. However, man marred this Imago Dei through sin, making the image increasingly less like the Creator's initial idea. This resulted in the creation being separated from the close relationship with the Creator, which in turn caused all kinds of crises, including the ecological crisis we have today.

Planet Earth has been systematically destroyed to the point that the currently available natural resources cannot be renewed to meet the needs of modern humanity. The ecological footprint, which consists of the totality of all human activities pertaining to the environment in a certain place, shows that the planet Earth has become "too small" to be able to meet all of humanity's needs. Mankind would require more than one and a half planets in order to create the natural resources necessary for the current rate of consumption. ${ }^{1}$ If we fail to take care of the problem and we do not become actively involved in protecting the Earth and in rationalizing the usage of scarce resources at all levels, a global catastrophe will come and life on Earth will become endangered. This will, consequently, endanger the survival of humanity, as well as plant and animal life.

Upon recognizing the signs of the times, during the Third Lausanne Congress on World Evangelization, which was held in Cape Town in 2010, among other topics there was also talk about ecology, which is particularly evident in the document's chapter seven entitled, We Love God's World. Since the gathering was attended by a large number of representatives from Evangelical churches from

1 Regarding mankind's impact on the planet see more at: Earth Overshoot Day: https://www. overshootday.org/newsroom/press-release-august-2020-english/ and at the World Ecological Footprint (WWF) website: https://wwf.panda.org/knowledge_hub/all_publications/ecological_footprint $2 /$. 
all over the world, the stance which was outlined in the form of a document also represents the view on ecology from an evangelical Christian standpoint. In desiring to consider the importance of considering ecology from the evangelical Christian standpoint, as well as its potential contribution to this relevant topic, we will use this paper to first analyze the relationship between theology and ecology, ie., the question of is there room for ecology in theology? After that, we will think about the ways in which the Biblical account of creation is supposed to inform and form the attitude of evangelical Christians towards the Earth. In part three, we will deal with the issue of the "ecological footprint" at a global level, and we will look at where is Croatia in all this. The fourth segment of the paper brings us a view on ecology through the prism of protestant and evangelical churches, while in the fifth segment we consider modern-day challenges and we offer two possible courses of action: the materialist-humanist way, and the protestantevangelical way.

\section{Theology and Ecology}

First, let us consider the following question: what is the relationship between speaking about God and speaking about God's creation? At first glance, we may not see any common points. However, a detailed approach to these two areas of science reveals that theology and ecology are mutually connected. In his book, Theology and Ecology, Simone Morandini $(2013,5)$ concludes that the connection between these two areas is very visible, "if only we take a glance at the international theological scene because it reveals the importance that has been devoted to environmental issues in the past decades. Earth as our common home (oikos) - this endangered common home - has become increasingly raised as an inevitable topic for theological contemplation." In line with the connection between theology and ecology, Carroll $(2005,287)$ emphasizes: "Theologically, the question of the environment relates to the creation theology. Ecology in the sense of caring practical for the Earth on which and from which people make their living also implies a solidarity with the generations to come."

Not enough attention is being paid in the world to environmental protection and its preservation. The Earth is being stubbornly polluted, the waters are getting dirtier and dirtier, and the air is filled with smog. The ozone is wasting away, we are rapidly cutting down and destroying forests and rain-forests, the ice caps are melting, and the sea levels are rising. Numerous meteorological and atmospheric changes are occurring. More and more frequently, humanity has been encountering extreme weather conditions in increasingly shorter intervals. Is this the Earth that God intended for mankind?

Through his intervention on Earth and his harmful actions, man has left a 
trace that is detrimental to ecological systems. The endeavors to protect the environment were initiated after the damage was already done. ${ }^{2}$ In the same way, the attempts to limit the production of plastic have been motivated by the results of research on the levels of pollution in the world's seas. Probing of at the North Pole, where no plastic mass elements should be found, revealed atoms of plastic (Katz 2019). This served to draw our attention to the fact that the entire food chain, including mankind, has been polluted by hard-to-break-down plastic molecules. The plastic which is dumped into the sea ends up in the digestive tracts of the fish, which are then caught and used in human consumption. On the other hand, global warming is causing climate change and it is disrupting the sensitive vegetative and climate balance, which is heading for a collapse. Melting of the polar caps, which is one of the key indicators of climate change, results in the sea levels rising, threatening with floods. We are being increasingly faced with catastrophic wildfires all over the world, leaving devastation in their wake. That's why Morandini $(2013,5)$ emphasizes:

We live in a dangerous society, where the environment has been exposed to threats on a global scale, to the point that these threats relate to each of us individually, as well as our children. This brought out to light a new understanding of our very being that theology is called to tackle in order to enable the light of the Gospel to shine in this space as well. This led to the development of intensive dialogue with those who are involved in the field of ecology (oikologia), and which seeks to understand its dynamics, logic, and articulation.

Ecology has redefined the behavior of contemporary humans. As man cares for himself, he also cares for the environment as a whole. The Christian understanding of ecology is far deeper than the humanist-anthropological benefit. It's not just a mere call to philanthropy. The Christian view includes the ecclesiological, theological, and eschatological views of the believer, who uses his actions to show and prove that he is a child of God. The community in which Christians act must be for the benefit of all people and all creation, in the right relationship with God, waiting to meet with God in the New Heaven and the New Earth. Roger Crook $(2002,267)$ emphasizes that for Christians, the concern for the environment is based on the ultimate theocentrism. The Christians' mutual responsibility towards one another is the result of their relationship with God. All human values, including the attitude towards nature, proceed from the values that people have towards God.

Ecological issues are relevant to every person. We need to be careful that all our activities regarding environmental protection do not make us lose focus on

2 More on the topic in the article: Kauffman, J. Boone, Robert L. Beschta, Nick Otting, and Danna Lytjen. 1997. An Ecological Perspective of Riparian and Storm Restoration in the Western Unites States. Watershed Restoration 22/5: 12-24. 
humanity. Humans are an important part of the ecosystem, and as such, they are responsible for maintaining it. This is why each person is required to be ethical in their dealings with nature. Ecology does not relate to humanity alone, but is a "science regarding the manifold relationships between living organisms and the environs they live in" (Kovačec 1996, 234). We often misidentify ecology with the idea of environmental protection, but it means much more than that. In its narrower sense, it encompasses the science of the correlation of the animal and plant life with their animate and inanimate surroundings (Klaić and Anić 1998, 350), and it represents the science about a way of life (Klaić 1990, 354). Because of all this, it has become a daily relevant theme in every culture in the world.

We can follow the relevance of theology throughout history, as well. One of the classics of ecological thought who was speaking out about the subject was Jean-Jacques Rousseau. He was born in 1712 in Geneva, in a Protestant family. His thinking involved promoting "the return to nature." When a person gets sick and tired of the noise, stench, and the alienating essence of the technological and economic colonization of life, they go back to the untainted, untouched nature, to the condition of original freedom they were born in before they were chained up in everything (Rousseau 1978, 94). And since every form of activism encounters opposition, so it was with him as well. His contemporary, Voltaire, sent him a letter in which he mockingly reviewed Rousseau's work entitled, Discourse on the Origin and Basis of Inequality among men published in 1755. Rousseau's thesis on the natural state and the man of natural state was hypothetically, historically, philosophically, and anthropologically necessary to be able to explain the new, civilized condition of mankind in the context of enlightenment rationality.

In the late $18^{\text {th }}$ century, Thomas Malthus noted in his book, Essay on the Principle of Population, that it isn't possible to keep expanding the Earth's capacities in order to meet the needs of the human population. Therefore, he concludes, wars, disasters, and starvation are necessary for maintaining the optimal world population. The book was published in 1798, and it discussed the current population of Great Britain.

Technological development and industrialization, which grew powerfully at the end of the $19^{\text {th }}$ and the beginning of the $20^{\text {th }}$ century, caused a gradual change in man's relationship with the environment. Until the 1950s, many people believed that natural resources were limitless (Pravdić 1992, 387). The increase in production sought to replace the increase in the demands caused by the rise in population. However, ecological problems began emerging in the second half of the $20^{\text {th }}$ century. In 1948, five days of a high concentration of smog caused the death of twenty and the poisoning of over 14 thousand of inhabitants of Donor, Pennsylvania. In London in 1952, smog caused the death of four thousand people (Crook 2002, 268). Problems such as these were the reason that at the UN 
conference in Stockholm in 1972 talks were initiated regarding sustainable development in the document called, World Conservation Strategy. More attention was given to air quality in cities, where measuring locations reported about the changes in harmful gas emissions. In 2016 the European Committee published a report about the air quality in Europe, pointing to the dangers of air pollution as the single greatest danger to the health in European cities (Ofrak 2017, 77). Numerous nuclear tests have made an impact on the flora and fauna of the world. Even today, after more than three decades later, we still talk about the consequences of contamination in East European countries which were affected by the Chernobyl disaster in 1986.

Today we are seeing attempts to impose the precedence of technology over nature. Humans are attempting to master over the Earth with the aid of technology. Natural resources are being mercilessly destroyed. Air, land, and water are getting more and more polluted, and the projects for sustainable development are insufficient. Everything revolves around man as the center of reality. Man's benefit and omnipotence are set as the main priority. However, we are losing sight of the fact that man has actually been continually showing signs of his own inability to solve the environmental issues which he has caused. Vjekoslav Glavač spoke up about this topic in his book, Uvod u Globalnu Ekologiju (Introduction Into Global Ecology). He summarized the results of man's actions in the $20^{\text {th }}$ century into seven points which describe the main reasons for the disturbance of the natural balance in the Earth's ecosystem. We can observe all seven points as the universal guidelines in analyzing sustainable development.

1. Most scientists think that man has contributed to global climate changes.

2. There is a correlation between the increase in greenhouse gasses and the increase in temperature in the lower layers of the atmosphere that has been statistically proven with $95 \%$ probability.

3. A large number of climate scientists still promote the stance that the warming so far is still within the limits of natural oscillations in the climate. They believe that relatively sudden changes have already happened during Earth's history. However, the impact of greenhouse gasses and aerosols in the process of global warming and climate change has still not been explained.

4. According to cautious computer prognoses, the average global temperature will rise by 2 degrees Celsius by 2100 , while others claim that it will increase by 5.8 degrees Celsius.

5. Higher temperatures will cause more intensive evaporation of water surfaces, which will increase the annual precipitation levels.

6. According to computer models, sea levels will rise by $35 \mathrm{~cm}$ by 2100 .

7. If we don't take radical measures to protect the environment by the end of 
the 21st century, the changes in the biosphere will have a strong effect on the further development of political, economic, and social circumstances (Glavač 2001, 89).

What kind of world will our society leave as a legacy for future generations? Will it be a paradise, or perhaps a desert? Lack of potable water, lack of food, the emergence and spread of infectious diseases, population migrations, unbearable heats - these are just some of the possible consequences of endangering the biosphere and life on Earth. The Earth has its limitations and resources which aren't infinite, making man's role more than somewhat significant. On that note, Gatti (2001, 172) emphasizes, "The discovery of the vulnerability of the natural environment, of the irreversibility of serious causalities started by technological processes and of amassing the consequences of such processes, are putting man's consciousness before an ethical chapter which has been unknown until now, but which is so important and crucial that it includes all previous forms of awareness regarding man's moral responsibility." With the aid of modern technology, man is able to not only produce new goods but also to destroy the entire created world. Thus, ethical questions are becoming more and more relevant. To rectify everything that is making people unhappy, we need to restore our natural environment as well, as one of the necessary prerequisites for restoring the "ecologically harmonious balance between man and nature" (Lane and Clark 2006, 72).

\section{Biblical Creation and the Creation's Crisis}

After an introductory review of the relationship between theology and ecology, we can now consider the ways in which the Biblical account of creation needs to inform and form the Evangelical Christians' attitude towards the Earth. In the Old Testament book of Genesis, we find the account of the creation of the world as the foundation of creation for all Christian church congregations. The creation of man was the pinnacle of God's creativity in creating the Earth and the Universe. Unlike animals, man was not given life with the sole purpose of perpetuating the species but was instead entrusted with a special task to be a steward over all of creation. The modern understanding that exploiting natural resources only has economic significance is present today as well. We can often see that owners of private properties also use those same properties for storing various kinds of waste. It is like they can do whatever they wish with their land. However, being a steward doesn't imply ruthless exploitation, but wise management of God's creation to maintain sustainable development.

The Scriptures speak of a close relationship between man and his "house" on Earth in which God had placed him (Gallo 2007, 340). God concludes the creati- 
on process by saying, "and God saw that it was good" (Gen. 1:10,12,18,25). After God created humans as male and female and he tasked them with managing all of creation, he finally ends the creation process by saying, "God saw all that $\mathrm{He}$ had made, and behold, it was very good." (Gen. 1:31). This was a way of creating harmony in creation. God created man in his own image. For this reason, man will never be able to find peace for his soul until he draws near to God. Man is a social being who was created for dialogue and relationship with God. However, by falling into sin, the first people became separated from God. Man became vulnerable and prone to sin. Today, due to his sinful nature, greed, and a desire to possess more and more natural resources, man is becoming prone to causing all kinds of crises, including ecological ones.

It was because of the Biblical account of creation that the Jewish understanding of nature and the created world differed from the Hellenist understanding of the kosmos. For the Jews, this was not a concept of natural law as a system of selfsustaining forces and regulatory principles. They didn't believe in natural law, but in God who is above all and who is in control over everything, making everything work. And while members of other Semitic nations viewed nature as an unpredictable reality which is comprised of numerous elements and is intertwined with man and his actions, the Jews did not approach nature and natural forces as deities, nor did they worship them. The Jewish perspective was vastly different from the modern stance on natural law as a system that is self-sustainable and regulated. The Jews did not believe in the natural law, but in a God who is directly in control over the entire creation. He is the one who makes everything work right. God is able to work through the nature of things and miracles because nothing is impossible for him.

The created nature, the world, and God stand in mutual and homogenous order. They are not mutually opposed, which would be a feature of kaos (Rebić 1996, 73). In Psalm 93 the Psalmist speaks of the Lord who rules over the Universe, and he reveals that there is an unbreakable bond between the creation and the Creator. Indeed, the world is firmly established, it will not be moved. And the Lord will rule forevermore, maintaining the harmony and order through his own Word. God is the Creator of nature and not the one who is supposed to identify with nature and its manifestations. Man is a part of the natural order, and he was created out of the dust of the earth. His creation was happening together with the creation of other parts, other lifeforms, and types of matter, including air, land, and water. God had given humanity a special place in his creation, which is why man needs to be accountable to him and to care for everything that God created because everything that God created was good (Crook 2002, 271-273).

Although in theophanies, which manifest God in a humanly tangible form, features were used which could be ascribed to natural occurrences, such as fire, 
storm, flame, lightning, earthquake, whirlwind, cloud pillar, the Jews were clearly emphasizing that God Yahweh is not under the influence of any forces, but that $\mathrm{He}$ has power over nature and its forces, and that $\mathrm{He}$ is able and willing to save Israel. Hence, when nature strikes man with affliction, this is not mere chance because it is the weapon of Yahweh's wrath (Hos. 8:7,9,14, Am. 4:7; Joel 2:111; Jer. 5:24). The Hebrew language does not distinguish between the "physical" and "moral" evil. Sin inevitably affects nature, because Yahweh is retracting His blessing and is using nature as the executor of His punishment. We can see the example of this at the beginning of Genesis after man has sinned, which resulted in smaller crops and growth of thorns and weeds. After evil has multiplied in the days of Noah, the global flood came as a consequence of human sin. This crisis of nature was connected to the crisis of man and his sinfulness. The claim that "all of the earth belongs to God" encouraged Harold K. Schilling (1972) to outline four views in regards to Earth. Shilling notes that the world is a single integrated ecosystem; each part of the world exists in and with a mutual relationship with other parts; all parts of the world strive for mutual unity, and reason and spirit are not specific to mankind alone but are characteristic of the entire ecosystem.

\section{The Stance Towards Ecology in Croatia}

The ecological footprint on a global level reveals that the current resources on planet Earth are not sufficient for meeting the needs of humanity today. The ecological footprint is the totality of all human activities relating to the environment in a certain area. It is about the activities humanity undertakes with the purpose of providing food, shelter, energy, caring for the environment, and transportation. The ecological footprint shows that the planet Earth has become "too small," which inevitably leads to inequality among humans. The current needs of humanity, which have been increasing daily, show us that we need approximately 1.6 planet Earths to create natural resources necessary for meeting current consumption (Meena and Yadav 2019,25). That is why it is no wonder that for many decades we turned the blind eye to environmental pollution to create larger quantities of goods and food.

Starting with the 1980s, man has begun exploiting the planet much more intensively than nature was able to restore itself. This means that the regeneration of forests is slower than cutting down wood, while water sources are being depleted faster than they're being renewed. Additional creation of waste is faster than its absorption or recycling (Edwing et al. 2010, 16-17). Scientists warn that we have never had such a high concentration of carbon dioxide in the atmosphere. The constant increase in the levels of greenhouse gasses has harmed the climate, global temperature increase, and bio-capacity. Bio-capacity refers to biologically arable surfaces, meadows, and wooded areas which are necessary for absorbing 
the carbon dioxide emissions which haven't been absorbed by the sea. Bio-capacity and ecological footprint are commonly referred to as, "global hectare" (gha). Technological development has to lead to further exploitation of limited resources. Technological advancement in modern agricultural and irrigation processes has to lead to a significant increase of crops per hectare. Between 1961 and 2010, biocapacity has increased from 9.9 to billion global hectares. At the same time, the human population grew from 3.1 billion to 7 billion, which ultimately meant a decreased biocapacity per capita from 3.2 to 1.7 global hectares. Projections for global population growth tell us that by the year 2050 the population will reach 9.6 billion people, with a constant decrease in biocapacity and biodiversity. We should add to this all the frequent climate changes which will harm the development of flora and fauna. Having all this data in mind, ensuring necessary daily food and water for the population of the Earth is going to prove to be a huge challenge. Thus, we can expect an increase in unrest, hunger, and disease (WWF 2014, 56).

According to the World Wide Fund for Nature report on the planet's condition $^{3}$ in 2014, Croatia is listed as one of the countries which have been excessively exhausting the Earth's resources. Croatia has been using the resources of 1.86 planets, ie., we are using more natural resources than we have at our disposal. In 2017, Croatia has been using the resources of 2.2 planets (Thomas 2017). With the increase of the total ecological footprint, this means that every following year we will be using up natural resources earlier than they can be replenished in a year. So Croatia entered its ecological debt on June $1^{\text {st }}$, while at the global scale it happened on August $1^{\text {st }}$. The fact that this period is getting shorter is proven by the fact that the Earth possessed sufficient natural resources up until 1970 when the Day of Ecological Debt happened on December $23^{\text {rd }}$, but ten years later it happened on October $13^{\text {th }}$, while in 2010 it happened on August $28^{\text {th }}$. In 2019 this number decreased to August $1{ }^{\text {st }}{ }^{4}$ One would expect that lowering population levels would also decrease the negative impact which the population has on the environment in an area. According to the report from the National Statistics Institute between 2009 and 2018, Croatia has been holding continuous negative population growth levels, which was -3.9 for 2018., and is equivalent to $-15,761$ persons. So the question arises: how is it possible that with a constant decrease in population their impact on the environment keeps increasing? Apart from the domicile population's impact on the environment in Croatia, tourists also

3 See the entire report for the condition of the planet in 2014 at: https://www.worldwildlife.org/ pages/living-planet-report-2014.

4 See at: https://www.rtl.hr/vijesti-hr/novosti/svijet/3541915/dan-koji-stize-sve-ranije-od-danas-zivimo-na-ekoloski-dug-potrosili-smo-sve-zemljine-resurse/. 
have a huge impact. There were more than twenty million foreign arrivals ${ }^{5}$ in 2019, which corresponds to the five-fold increase in the Croatian population. The development of tourism is tied in with the development of entertainment, accommodation, and infrastructural projects which have an additional impact on the environment. Biškup $(2000,49)$ emphasizes that "modern industrialization provided modern man with multiple benefits and numerous conveniences in everyday life, but it also brought him into a dangerous imbalance with his closest environment and the nature which surrounds him... Modern industrial advances were made under the motto, "more, faster, and longer," but without taking care of long-term consequences of said advances in economic and social areas." This is why some developing countries believe that environmental pollution is the price for technological advancement, while at the same time developed countries, which have been exploiting natural resources in the past decades, now became leaders in ecological activism. However, as is emphasized by Tomašković $(2000,23)$,

"Blind development and technological advancement must no longer have the main say in human life, because they can lead to a global disaster affecting all of us on the planet. Today's technology is showing exceptional interest in the ecological problems of the world, so much so that there is a new branch of this scientific discipline emerging which could be called eco-theology, which has the purpose of exploring how should man live in harmony in this house that is the world."

Since Croatia is a Christian country, one would expect that its citizens are keeping, or are at least trying to practice the biblical attitude towards ecology to some degree. But is that the case? ${ }^{6}$ According to the National Statistical Institute's ${ }^{7}$ Statistic report from 2013, the total number of Christians (Catholics, Eastern Orthodox, Protestants, and other Christian denominations) was 3,914,900 people, which is $91 \%$ of the Croatian population. According to the report of the Croatian Agency for the Environment and Nature, the total amount of produced municipal waste in 2016 was $1,679,765$ tons. This means that the production of munici-

5 More about tourist results in 2019 at: https://hrturizam.hr/resume-2019-godine-ostvareno21-milijuna-dolazaka-i-1086-milijuna-nocenja/.

6 The problematic of the huge gap between claiming that we are Christians (on Sunday) and our practical life on Monday in Croatia was discussed by Dražen Glavaš in his articles, "Christian on Sunday, atheist on Monday: How To Bridge the Gap Between Faith and Work In Croatian Culture." Kairos, 11/1 (2017): 29-67, and "Christian on Sunday, atheist on Monday: How To Bridge the Gap Between Faith and Work In Croatian Culture, part II“. Kairos, 11/2 (2017): 169-198.

7 See more statistical data at: https://www.dzs.hr/Hrv_Eng/publication/2012/SI-1469.pdf. 
pal waste per capita is $392 \mathrm{~kg}$ per year. ${ }^{8}$ The percentage of mixed municipal waste was $74 \%(1,251,299 \mathrm{t})$, while the separated waste was only $26 \%(428,466 \mathrm{t})$. This data shows that citizens of Croatia have produced $291 \mathrm{~kg}$ of mixed municipal waste, and only one third or $99.6 \mathrm{~kg}$ of separated waste per year. Thus, Croatian society is practically proving that it is not yet sufficiently ecologically aware, and the Christian faith's biblical view on the creation of the world sure can and should make its contribution in that respect.

\section{Viewing Ecology from the Standpoint of Protestant and Evangelical Churches}

The Bible teaches that man, who has been separated from God, is sinful and that the evil that is within him comes out from him and spills over into his behavior and relationships. In other words, it spills over into the world and the society around him. In this sense, the problem of ecology is, in its roots, a theological one. Therefore, the cause for excessive exploitation of natural resources can be found in the individual's greed and in maximizing profits. Sometimes even science can be one of the tools used to that end. In the article, "Safeguarding and Development of Creation: Principle of Cautiousness - A Scientific Correction of Greed," Valerija Vrček $(2006,424)$ emphasizes that greed is an intrinsic temptation of science, "but a structural contamination of science which occurs due to its bonds with industry and ideology... Greed is, therefore, not the only malformation of science, but it is very important in the context of considering the 'safeguarding of creation' because it causes permanent consequences in physical space. Particularly ecological ones..."

Due to the industrial revolution and sudden technological development, the reserves of natural resources started depleting rapidly. Today we've reached a critical point where caring for the environment is no longer a choice, but a necessity. Without this kind of approach, we will not be able to sustain life on Earth. More than half of changes in the biosphere occurred after 1945, while in the 1990s we have reached the point of endangering the entire planet Earth (Tomašković 2000, 26). Evangelical Christians did not just stand by watching the ecosystem collapse. "As soon as the world was warned about the ecological disaster that is ahead of us, Christians immediately stood along with the ecophiles. Christ's churches in the USA formed a task force called, Faith - Man - Nature, as early as 1964, with the purpose of preserving nature" (Živan 1990, 54). They had a task to use theo-

8 Data on the amount of waste in Croatia is availabel at: HGK.02.05.2018. Gospodarenje otpadom u Republici Hrvatskoj 2018. https://www.hgk.hr/documents/pgo-prezentacija-hgk-burzaotpada-2520185aeb13c483058.pdf (accessed on Feb 17 $7^{\text {th }}$ 2019). 
logical reflections regarding the importance of nature and man's impact on it to encourage those with the responsibility in society to actively solving structural ecological problems (Skledar 1995, 847).

Theological reflections dealing with the topic of the Earth were first published mostly by Protestant theologians. German evangelical theologian Gerhard von Rad was involved in researching and analyzing the Earth in part of his paper, Verheisenes Land und Jahwes Land im Hexateuch, published back in 1943. At the time, not many people thought about the need to take care of the Earth which they've inherited from their ancestors to use it wisely. In Switzerland in 1956, Protestant theologian Hans Wildberger dealt with the Biblical understanding of the Earth in his article entitled, Israel und sein Land, by analyzing the notions of possession, heritage, and property. German Evangelical theologian Friedrich Horst published a paper in 1961 called, Zwei Begriffe fur Eigentum (Besitz), and four years later German Protestant theologian Leonhard Rost published a significant article entitled, Die Bezeichnungen fur Land und Volk im Alten Testament. American Protestant theologian Walter Brueggemann wrote his work, The Land: Place as Gift, Promise, and Challenge in Biblical Faith in 1978. We can conclude that Protestant theologians have made a very important contribution to the development of theological ecological thought. The first Evangelical work on the topic of creation was written by Francis Schaeffer in 1971 called, Pollution and the Death of Man. In the same year Biblical theologian and philosopher at the Southern Baptist Theological Seminary, Eric Rust published his paper, Nature - Garden or Desert? The very next year, in 1972, Henlee Barnette published The Church and the Ecological Crisis. Many Christian denominations have formed ecological departments, and care for the environment began spreading progressively in Evangelical circles. The year 1973 saw the founding of the organization, Evangelicals for Social Action, with the Chicago Declaration as their foundational document. In 1986, Ron and D'Aun Goble founded the Christian Environmental Association (Stassen and Gushee 2003, 428).

At the first general assembly of the Ecumenical Council of Churches held in Amsterdam between $22^{\text {nd }}$ of August and $4^{\text {th }}$ of September 1948 talks were initiated about restoring the world and repairing the damage caused by wartime activities. The third section was entitled, The Church and the Disorder in Society. Even back then there was talk about a divided world which craved for restoration and a responsible society (Macut 2017, 90). During the 1970's we started talking about the importance of the environment.

At the fifth general assembly of the Ecumenical Council of Churches held in Nairobi in 1975, which was entitled, "Christ Delivers and Unites", the sixth section was called, "Development of Mankind: The Ambiguity of Power and Technology and the Quality of Living" (Macut 2017, 124). Representatives from 
the aforementioned organization, Evangelicals for Social Action, were called to attend this very conference. It was emphasized that the Church's mission was not to stand aside, but that it is the reality which aids the development of society by fighting poverty, injustice, and through a more righteous distribution of wealth based on justice, freedom, and peace. The development of society and technological advancement in particular must be focused on humans and ensuring their basic spiritual and material needs. It was concluded at the conference that mankind needs to wake up if it wants to survive. Technological development is leading humanity into potential new disasters, so we urgently need a risk assessment. Apart from the risk assessment, there is also talk about saving and smartly distributing energy, and nuclear energy is being given a special kind of emphasis. Thinking about energy, there was also the unavoidable topic of technologies and their utilization of alternative energy sources to preserve the environment and the Earth (Macut 2017, 125).

During the 1970s there was more and more talk about environmental protection in ecumenical circles since the environment had become endangered due to technological advancement (Frieling 2009, 251). The topic of "Environment and Destruction of Natur" was dealt with in 1971, while the topic of "Genetics and Quality of Life" was covered in 1973. At the "conciliar process for righteousness, peace, and safeguarding of creation" held in 1983 in Vancouver there was talk about the matters of righteousness, peace, and protection of plant and animal life, which converged with the individual's work ethics.

The ecumenical assembly in Basel which was held in 1989 was the first time where representatives from all Christian churches came together, including the Catholic Church, which was represented by Cardinal Carlo Martini. At the assembly, there was talk about endangering the nature, endangering peace, and endangering the environment (Japundžić 2017, 6). This was followed up by the assembly at Seoul in 1990, where it was emphasized in article 5 that "God loves the creation. The delegates present have committed to act with the purpose of preserving the Earth's atmosphere and creating a culture which will be able to live in harmony with the entire creation. The following year, in 1991, the assembly was held in Canberra, and it was in 1997 in Graz that the "Ecumenical Charter for Increasing Cooperation Between Churches in Europe" (Charta oecumenica) was adopted. The ninth chapter of the Ecumenical Charter speaks about the ecological responsibility of man. According to the Charter, Christians are called to this:

Believing in the love of the Creator God, we give thanks for the gift of creation and the great value and beauty of nature. However, we are appalled to see natural resources being exploited without regard for their intrinsic value or consideration of their limits, and without regard for the well-being of future 
generations.

Together we want to help create sustainable living conditions for the whole of creation. It is our responsibility before God to put into effect common criteria for distinguishing between what human beings are scientifically and technologically capable of doing and what, ethically speaking, they should not do.

We recommend the introduction in European churches of an Ecumenical Day of Prayer for the Preservation of Creation. We commit ourselves to strive to adopt a lifestyle free of economic pressures and consumerism and a quality of life informed by accountability and sustainability, and to support church environmental organizations and ecumenical networks in their efforts for the safeguarding of creation. ${ }^{9}$

Charter signatories represented the members of the Conference of European Churches (KEK), comprising of over 120 representatives from Christian churches (such as Anglicans, Old Catholics, Eastern Orthodox believers, Protestants, and representatives from Reformation heritage churches), and from the Council of the Bishop's Conferences in Europe (CCEE), which gathers 34 European Bishop's Conferences. In this way, the Charter was signed by representatives from all Christian churches. By agreeing on the topic of safeguarding everything that was created the document made its contribution in the area of environmental protection. When it comes to the challenge of aligning the things which are scientifically and technically feasible with ethics, the document clearly states that the unique dignity of every human being must be the priority over technically feasible things. Since the Earth is an inherited good, Christians need to treat it as an inheritance which will be passed on to the next generation, and not as property. Recognizing the seriousness of the situation that the Earth is in, "churches in Europe have called Christian churches to introduce an ecumenical day of prayer, which would be dedicated to praying for safeguarding all of creation" (Macut $2013,152)$. This was a very specific idea, which was implemented four years later by the representative of the Catholic Church, Pope Francis, in 2015 when he proclaimed September $1^{\text {st }}$ to be the first World Day of Prayer for the Care of Creation. ${ }^{10}$

The Lausanne Congress bears a special significance for evangelical Christianity in the world. The International Congress of evangelical Christians on World Evangelization was first held in 1974 in Europe, in Lausanne, Switzerland. It was the largest gathering of evangelical Christians to date, with over 2700 delegates

9 Croatian translation of the Ecumenical Charter is available at: Savez baptističkih crkava u RH, 2019. Dokumenti, https://www.baptist.hr/images/Download/Ekumenska_povelja.pdf (accessed on January $20^{\text {th }} 2019$ ).

10 More about the event at: https://ika.hkm.hr/novosti/molitva-u-obitelji/. 
from 150 countries in one place. The Second Congress was held in 1989 in Asia, in Manila, The Philippines. The Third Lausanne Congress on World Evangelization was held in the African city of Cape Town in 2010, where 4200 church leaders from 198 countries of the world gathered. Delegates from Croatia ${ }^{11}$ also attended the Cape Town Congress. The document which resulted from the Congress was titled The Cape Town Commitment, and chapter 7 entitled, "We Love God's World" brings us a brief view on ecology from the standpoint of evangelical Christianity. According to it, evangelical Christians are not called to stand aside and observe what's happening in and to the world; instead, they need to show a fervent interest on behalf of the world, loving everything that God has created, ie., loving the world of God's creation. This kind of love is not a mere sentimental affection towards nature or a sense of worship towards nature. The document emphasizes that "it is the logical outworking of our love for God by caring for what belongs to him. 'The earth is the Lord's and everything in it.' The earth is the property of the God we claim to love and obey" (TCTC 7A). Evangelical Christians need to care for the Earth, which belongs to the Lord by right of creation, redemption, and inheritance. Caring for the Earth and responsible use of its resources is the Christians' task, not because of the world's reasoning and legal regulations, but because of Jesus Christ. The document explains this attitude by saying, "If Jesus is Lord of all the earth, we cannot separate our relationship to Christ from how we act in relation to the earth. For to proclaim the gospel that says 'Jesus is Lord' is to proclaim the gospel that includes the earth, since Christ's Lordship is over all creation" (TCTC 7A). Love for God's creation is seen in the everyday practical lives of evangelical Christians. It requires "that we repent of our part in the destruction, waste and pollution of the earth's resources and our collusion in the toxic idolatry of consumerism" (TCTC 7A). It is very easy to fall under the influence of the masses and to adhere to a way of life that does not take the balance in God's creation into account. In his sinful nature, man is prepared to accept many compromises to satisfy his needs.

The Cape Town Commitment delves deeply into the topics of love and serving. The first section includes The Confession of Faith, while the second section is the call to action. Even though it only deals with the topic of ecology in principle, as part of the topic of loving God's world, there is still a clear exhortation and the direction of action evident in the document. Thus, it says the following, "Instead, we commit ourselves to urgent and prophetic ecological responsibility. We support Christians whose particular missional calling is to environmental advocacy and action, as well as those committed to godly fulfillment of the mandate to provide for human welfare and needs" (TCTC 7A). Although we will say

11 See report: https://www.baptist.hr/novosti/388-otvoren-rad-lausanne-3-u-cape-townu 
more about the activities of some missionary organizations from the Evangelical Christian world a bit further in the text, it is important to emphasize that the document presupposes that Christ's mission call includes completeness. This means that mission involves discernment, proclamation, and living Biblical truth according to the "gospel (that) is God's good news, through the cross and resurrection of Jesus Christ, for individual persons, and for society, and for creation. All three are broken and suffering because of sin; all three are included in the redeeming love and mission of God; all three must be part of the comprehensive mission of God's people" (TCTC 7A).

Ethicist Norman Geisler also spoke out about the topic of ecology from an evangelical perspective. According to him, it has a theistic outlook within the Judeo-Christian context, which implies that all of Earth and the Universe reflect the glory of the Creator (Ps. 19:1). Thus, Christian ecology finds its source in Christian theology. As is stated in Psalm 24:1, "The earth is the Lord's, and all it contains," the Earth is Yahweh's property, but even though God owns the Earth, he has given man the privilege to work it and manage it. Evangelical Christians have thus been called to be fervent and determined in their effort to safeguard God's world and everything God has created. This task should not be a burden to them, but gratitude to God for his provision in creation, because everything has been so wondrously made in perfect harmony. In God's act of creation, man is the most exalted creature, made in his own image (Imago Dei). God is the one who maintains order in the Universe and like Paul, the apostle, told the Church in Colossae, "in Him (i.e., God) all things hold together" (Col. 1:17). "Since God is the one who holds and rules the natural world which is necessary for sustaining life, ecological involvement in His works is the crazy courage on the part of creation, which bears serious ethical implications" (Geisler 2005, 299).

God did not create the world and then leave it on its own. God is still watching over his creation, and man is considered as the wise manager and keeper of God's creation and environment. For example, in the covenant between God and the world we find God's promise, "I will remember My covenant, which is between $\mathrm{Me}$ and you and every living creature of all flesh; and never again shall the water become a flood to destroy all flesh." (Gen. 9:15). Earlier in Genesis 1:28, we find God's commandment to man, "Be fruitful and multiply, and fill the earth, and subdue it; and rule over the fish of the sea and over the birds of the sky and over every living thing that moves on the earth." In Genesis 2:15, near the end of the creation account, God places man in paradise. "Then the Lord God took the man and put him into the garden of Eden to cultivate it and keep it." Based on these biblical verses, we can say that man has been called to manage the world responsibly and to not waste natural resources, turning God's garden into a wasteland, and His seas into quagmires. 
Norman Geisler holds that God commanded man to fill the Earth, not to overcrowd it. ${ }^{12}$ The Scriptures are not just listing some general conclusions regarding our responsibility for the environment, but gives us practical advice for maintaining it. Some laws relate to man's righteous relationship towards the environment, and the author goes on to explain them individually. Those include the Law of good stewardship, the Law of Sabbath rest, the Law of the land resting, the Jubilee law, the Harvest law, the Laws about health measures, the Law of warfare, the Law against greed over land (Geisler 2005, 301-302). According to Geisler, all these laws speak about the relationship with nature and with God's creation. Thus, ecology implies good management. Weekly rest is not just meant for humans, but animals as well. The land was supposed to rest every seventh year to recover for the next six-year harvest cycle. God owns the land, not man. People are only allowed to occupy it temporarily, and after the Jubilee the land would be returned to its rightful owner, preventing exploitation. Gleaning was not allowed during harvest season so that the poor and the animals would have something to eat. Furthermore, Leviticus clearly warned the people of Israel of the importance of cleanliness for health, while human waste was supposed to be buried in the ground. Even in wartime, God was warning the Israelites that they must preserve the environment, and not destroy the land they were conquering. God never approved of greed. Greed for land destroys its productivity, causing decreased harvests. To make up for what was lost, farmers resort to using various artificial solutions that pollute the ground, in turn polluting the crops used for food.

If the Scriptures give us practical advice for preserving the environment, it is not surprising if Geisler believes that the Christian world is, to an extent, also partly responsible for the ecological crisis. Christians are not always faithful witnesses to Christian principles. By polluting the environment, man is polluting his food and water. In this way, he is not only sinning against the environment but also against himself and against his neighbors who are being denied a chance for a decent life. And ultimately, he sins against God himself (Geisler 2005, 304). Based on all this, we can say that Geisler provided a good summary of ecology from the evangelical perspective, but he also points to the problems and shortcomings that evangelical Christians are not exempt from, either.

12 Average human life expectancy, according to Anadolu Agency (AA) between 2000 and 2016 was extended from 66,5 to 72 years (Altuğ 2019). The increase of the number of newborns and the population getting older lead to overpopulating Earth, and consequently to using up the scarce food resources. The balance between plants, animals, and humanity has been restored. Considering this condition, mankind is to doomed to extinction through starvation and conflicts. 
Through their responsible behavior towards nature and the entire creation, evangelical Christians are showing practically their relationship towards the founder and creator of nature and all of creation. By loving the world of God's creation we show love towards God the Creator. It is the foundation on which we need to build his Kingdom, proclaiming the Good News to every creature and all nations as we long for the day when the entire Earth will be filled with God's glory. Evangelical Christians need to use their example and their activities against nuclear arming and polluting natural resources to show their engagement in preserving the world which God has created so miraculously. The Cape Town Commitment expresses the evangelical stance that nature, the environment, and the world aren't bad in and of themselves or something that needs to be destroyed because it was contaminated by sin as we await the "New Heaven and New Earth." It was Christ who created the Earth by his Word and ransomed it by His life and He maintains it. We cannot support evangelical Christianity without simultaneously caring about the responsible utilization of the Earth and its natural resources. Christ's lordship over all the Earth is expressed in the personal lives of the individuals, as well. Love for God is expressed through love towards our neighbor and the entire God's creation which needs to be guarded, and not destroyed.

\section{The Challenges of Our Day}

The world is in a crisis and many nations lack sufficient food supplies due to inadequate distribution, and it is precisely global education that can contribute towards adequate distribution. Along those lines, Bekavac $(2014,359)$ emphasizes: "These times carry in themselves the awareness of the fragility of our planet in the Universe. Only man has the power and the ability to actively change his environment and his life. Instead of a space for human life, we've got a space filled with fear and apocalyptic visions of the end of the world." Man has come face to face with the global threats of nature's capacities to produce the goods for the members of society on one hand, and to replenish them on the other (Rasmussen 1996, 5). Therefore, caring for the environment implies values such as respecting the creation, preserving Earth's resources, and the responsibility towards other people on the planet who are in danger. Humanity, which is the largest part of nature, must understand that it is dependent on those things which it has not destroyed yet. Yes, factory facilities and industry, in general, are the main forces which spend, pollute and destroy what God has given man, but this is not some nature which is outside of man's surroundings; it is part of the total creation and the remaining part of creation that is crucial for human life on Earth (Stassen and Gushee 2003, 429). So a lot depends on man, but the question is: what do we need to do to resolve all these problems? 
Contrary to the previously outlined view on ecology from the standpoint of Protestant and Evangelical churches, there is also a materialistic view, which was presented in the Humanist Manifesto I from 1933. It is rooted in the atheist-secular-humanist outlook, which claims that nature simply exists, but God does not. Nature was not created but is at humanity's disposal. Materialists believe that energy is indestructible, and thus unlimited and that human technology can solve virtually any problem. Whatever cannot be done by technology and science, it can be done through political power.

On the other hand, awareness about ecological problems has connected all Christian churches to start working together to preserve the environment where man lives and works. The decision of whether we place a plastic bottle or plastic bag in mixed waste or the recyclables reveals the individual's attitude towards God and their Christian ethics. Christian ecological activities start in the Christian home, with practicing separating waste and guarding natural resources. "Although it might appear like ecological awareness and responsibility among Christians has increased in the previous years, it still seems that enacting the ecumenical documents which speak about safeguarding nature and the environment has not yet caught on at the level it should have" (Japundžić 2017, 6). A person who loves Christ doesn't abuse that which belongs to Christ by right of creation, redemption, and inheritance. The fundamental ethical task is reflected in our care for ecology, but not according to the world's reasoning, rather because of our Lord. Jesus is Lord, and the Christian's attitude towards the Earth is indicative of his attitude towards Christ, thus we cannot separate our relationship with Christ from the way we treat the Earth. Care for the environment "which stems from the correct understanding of the Biblical message becomes even more urgent if we look at the creation as the handiwork of the Triune God. Everything comes from the Father, through the Son, in the Spirit" (Salvati 2009, 253). Jesus is Lord over all creation. Christians need to be ecologically proactive. Their care for the environment is Gospel-mandated, and it stems from Christ's Lordship.

Looking at Christ's ministry, we can pick out at least two elements that he emphasized that have to do with our attitude towards the creation: 1. God provides, and 2. Greed doesn't work. In the Gospel of Matthew 6:19-34, Jesus clearly states that God provides for the birds and the lilies in the fields. God makes sure that the seeds sprout in the fields; He gives the gifts of rain and sun to all people. Jesus also spoke about investing in money, in treasuries full of riches, and about serving the riches as the god mammon, which leads to creating a powerful vicious circle. By investing his money, man will show where his heart is. Because, according to Jesus' words, if a person wishes to serve both God and greed at the same time, they will inevitably hate one and love the other. The history of mankind shows that the way man has 
been rapidly destroying the creation points to the fact that he prefers short-term riches and hates God's care for the creation (Stassen and Gushee 2003, 429).

As we face modern-day challenges, Christians from all denominations and traditions must be aware that if they wish to bring forth the fruit of love for God's creation, they are required to repent for their active and passive participation in destroying, devastating, and polluting Earth's resources. Through his uncontrollable consumerist habits, man buys and uses up more resources than is necessary for his survival. By doing this, he's making a negative impact on the environment, and caring for the environment should very much be part of the Christian ethos. As for evangelical churches, their representatives have readily committed to urgent ecological responsibility, which resulted in supporting activities of evangelical Christians who have found their mission calling in promoting and actively caring for the environment. Large antinuclear protests were held during the 1980s in the USA, and hundreds of thousands of people participated in them, and they were supported by some religious groups, such as the members of the Southern Baptist Convention and the Episcopal Church. The United Church of Christ asked for a total ban on nuclear weapons, which is spoken about in the book, Just Peace, published in 1985. The following year, in 1986 the United Methodist Church published a book called, In Defense of Creation: The Nuclear Crisis and a Just Peace, which spoke against the existence of nuclear weapons (Thistlethwaite 2010). In February 2006, a group of 86 prominent American Evangelical Christians started an initiative called, Evangelical Climate Initiative (ECI). Together with the National Association of Evangelicals (NAE) and the Center for Health and the Global Environment of Harvard Medical School, ECI gathered scientists and evangelical Christian leaders to start proactively working on diminishing climate changes. This cooperation resulted in creating a common document about protecting the creation, ${ }^{13}$ with the main purpose of decreasing carbon dioxide emissions and stopping global warming. The Evangelical Environmental Network - EEN in the USA encouraged younger generations to become involved in ecological activism as well, through Young Evangelicals for Climate Action (YECA), and "its purpose is to mobilize students, influence religious leaders, and leverage legislative bodies with the purpose of legislating laws which will help solve climate changes" (Subramaniam 2018). It's also worth mentioning Christian ecological organizations such as, Climate Caretakers, Care of Creation, and A Rocha International, which advocate for clean air and water, and a stable climate. Through their actions, evangelical Christians who are gathered in these and other similar associations are contributing to the struggle to preserve the environment and protect natural

13 The document is called, "An Urgent Call to Action: Scientists and Evangelicals Unite to Protect Creation", and it's available at, https://www-tc.pbs.org/now/shows/343/letter.pdf. 
resources. However, we need to do more in this field, which is still a challenging one. It is important to strengthen ecological awareness among believers and to help the ecological stance from the standpoint of evangelical Christianity become a more common practice in evangelical churches.

\section{Conclusion}

The purpose of this overview was to warn about the emergence of the topics of ecology and environmental protection in Protestant and Evangelical Christianity. Based on everything we have said so far, we first need to emphasize that ecological crises are a consequence of mankind's fallen and rebellious condition before God. In other words, ecological crises are in direct correlation with the moral crisis, and a change in the attitude towards ecology is achieved through raising ecological awareness and conscientiousness of individuals as members of society. However, all these activities which are implemented to preserve the environment without changing man's essence, and consequently his habits, will only yield short-term results with no crucial changes. Only by changing man himself and through his repentance can he become responsible in his ethical approach towards the environment that surrounds him.

And it is precisely because of Christ's salvific and redemptive work that Christianity can provide answers and solutions for the modern ecological problems and crises: biblically speaking, a new man who will not destroy but build; who will not hoard bit will sow; who will not exploit but will wisely manage, making sure that he leaves a better and richer than what he has himself received and inherited. On that note, Christians are called to be proponents of ecology and preserving the environment. They are called to admire God's creation and to maintain it. As God's children, Christians are called to obey the will of the Heavenly Father and to be an example and a light in the egotistical world of today.

In the Cape Town Commitment, Evangelical Christians have made their contribution to the importance of ecology by calling on Evangelical churches to start acting prophetically. By recognizing that our love for God includes our love for His creation and that it is impossible to separate our relationship with Christ from the way we treat the Earth, the Cape Town Commitment clearly emphasizes that a full Christian mission implies proclaiming and living in accordance with the Gospel, which is the Good News, not just for the individual, but for society and the creation as a whole. Along the same lines, we can say that being a Christian doesn't just mean nominal affiliation with a Christian community but also implies an active Christ-centered life that reflects following Christ in the area of ecological activities and attitudes, as well. Such an individual cares for the protection and keeping God's creation out of their love for the Lord. Christians are called to 
be leaders in ecological initiatives and to promote raising awareness about ecology and preserving the Earth, which is home to all people. And we need to do that with hope, knowing that we are waiting for the fullness of redemption which was started by Christ. Or, in the words of apostle Paul, "For the anxious longing of the creation waits eagerly for the revealing of the sons of God. For the creation was subjected to futility, not willingly, but because of Him who subjected it, in hope that the creation itself also will be set free from its slavery to corruption into the freedom of the glory of the children of God" (Rom. 8:19-21).

\section{Bibliography}

Altuğ, Bayram. 2019. SZO: Human average life expectancy has been extended by 5.5 years. Anadolu Agency, April 4 ${ }^{\text {th }} 2019$, https://www.aa.com. tr/ba/\%C5\%BEivot/szo-prosje\%C4\%8Dni-\%C5\%BEivotni-vijek\%C4\%8Dovjeka-produljen-za-5-5-godina/1442788 (accessed on August 10, 2020).

Barbour Ian, ed. 1972. Earth Might Be Fair: Reflection on Ethics, Religion and Ecology. Englewood Cliffs: Prentice Hall.

Bekavac, Ante, and Franjo Podgorelec. 2014. Suvremeni izazovi globaliziranog svijeta. Bogoslovska smotra 84/2: 349-366.

Bezić, Živan. 1990. Kršćanin i ekologija. Crkva u svijetu 25/1: 47-58.

Biškup, Marijan. 2000. Ekološki problemi u spisima pape Ivana Pavla II. Socijalna ekologija 9/1-2: 49-60.

Billings, B. Dwight and Will Samson. 2012. Evangelical Christian and the Environment: "Christians for the Mountains" and the Appalachian Movement against Mountaintop Removal Coal Mining. Worldviews: Global Religions, Culture and Ecology 16/1: 1-29.

Brueggemann, Walter. 1978. The Land: Place as Gift, Promise and Challenge in Biblical Faith. London: SPCK Publishing.

Carroll, Denis. 2005. Suvremena katolička enciklopedija. Split: Slobodna Dalmacija.

Crook H. Roger. 2002. Christian Ethics. New Jersey: Pearson Education.

Frieling Rainhard. 2009. Put ekumenske misli. Zagreb: TFMVI.

Edwing et al. 2010. Ecological Footprint Atlas 2010. Oakland: Global Footprint Network.

Gallo, A. Luis. 2007. Kršćanski angažman u korist ekologije. Kateheza 29/4: 340-348. 
Gatti, Guido. 2001. Ekologija. Kateheza 23/2: 169-176.

Geisler, L. Norman. 2005. Kršćanska etika. Zagreb: Bogoslovni institut.

Glavač, Vjekoslav. 2001. Uvod u globalnu ekologiju. Zagreb: Hrvatska sveučilišna naklada.

Japundžić, Antun. 2017. Ekumenizam i ekologija. Diakovensia 25/1: 5-7.

Katz, Cheryl. 2019. Tiny pieces of plastic found in Arctic snow. National Geographic, 14. kolovoza 2019. https://www.nationalgeographic.com/ environment/2019/08/microplastics-found-in-arctic-snow/ (accessed on August 12 ${ }^{\text {th }}$ 2020).

Klaić, Branko. 1990. Rječnik stranih riječi. Tuđice i po na suđenice, Zagreb: NZ Matice Hrvatske.

Klaić, Nikola and Šime Anić. 1998. Rječnik stranih riječi. Zagreb: Sani-plus.

Kovačec, August, ed. 1996. Hrvatski opći leksikon. Zagreb: Leksikografski zavod Miroslav Krleža.

Lane, H. Joseph, and Rebecca R. Clark. 2006. The Solitary Walker in the Political World. The Paradoxes of Rousseau and Deep Ecology. Political Theory 34/1: 62-94.

Macut, Ivan. 2017. Suvremeni ekumenski pokret - Svjetske konferencije (1910. - 2013.). Pokret za život i djelovanje - Pokret za vjeru i ustrojstvo Crkve Ekumensko vijeće crkava. Zagreb: Glas Koncila.

Meena, Kumar Ashvin i Tikendra Kumar Yadov. 2019. What is Ecological Footprint and Why is it Important? Agrobios Newsletter 18/1:25-27.

Morandini, Simone. 2013. Teologija i ekologija. Zagreb: Kršćanska sadašnjost.

Ofrak, Lana. 2017. Legal protection of air in European and Croatian legislation. In: Jakša Barbić, ed. Pravna zaštita zraka, 77-102. Zagreb: Hrvatska akademija znanosti i umjetnosti.

Pravdić, Velimir. 1992. Morskim putem od Stockholma do Rio de Janeira. Socijalna ekologija 1/3: 387-397.

Rasmussen, Larry. 1996. Earth Ethics. New York: Orbis.

Rebić, Adalbert.1996. Središnje teme Staroga zavjeta. Zagreb: KS.

Rousseau, J. J. 1978. Rasprava o porijeklu i osnovama nejednakosti medu ljudima. Društveni ugovor. Zagreb: Školska knjiga.

Salvati, M. 2009. Ekologija. In: Aldo Starić, ed. Enciklopedijski teološki rječnik, 252-254. Zagreb: KS.

Schilling, Harold H. 1972. The Whole Earth is the Lord's: Toward a Holistic Ethic. In: Ian G. Barbour, G. Earth Might be Fair: Reflections on Ethics, Religi- 
on, and Ecology, 110-122. New Jersey: Prentice-Hall.

Skledar, Nikola. 1995. Sakralna ekologija i čovjekov prirodni okoliš. Društvena istraživanja 6/4: 867-883.

Stassen, H. Glen and David P. Gushee. 2003. Kindom Ethics. Downers Grove: IVP.

Subramaniam, Meera. 2018. Generation Climate: Can Young Evangelicals Change the Climate Debate? InsideClimate News, 21. studenog 2018. https://insideclimatenews.org/news/21112018/evangelicals-climate-change-action-creation-care-wheaton-college-millennials-yeca (accessed on August $12^{\text {th }} 2020$ ).

The Cape Town Commitment (TCTC). Lausanne Movement. https://www.lausanne.org/content/ctcommitment (accessed on August 12 $2^{\text {th }} 2020$ ).

Thistlethwaite Susan Brooks. 2010. Let's Take Religious Nuclear Opposition to the Next level. Center for American Progress, April 12, 2010 https://www. americanprogress.org/issues/religion/news/ 2010/04/12/ 7662/lets-takereligious-nuclear-opposition-to-the-next-level/ (accessed on August $12^{\text {th }}$ 2020).

Thomas, Mark. 2017. Croatia is using resources of 2,2 planets - Global Footprint Network. The Dubrovnik Times, July $29^{\text {th }} 2017$. https://www.thedubrovniktimes.com/news/croatia/item/2809-croatia-is-using-resources-of-2-2-planets-global-footprint-network (accessed on September 12 $2^{\text {th }} 2020$ ).

Tomašković, Luka. 2000. Ekologija: Izazov kršćanstvu. Socijalna ekologija 9/1-2: 23-33.

Vrček, Valerije. 2006. Preserving and developing the creation: The principle of cautiousness - a scientific correlation with greed. Bogoslovska smotra 76/2: 417-427.

WWF. 2014 Living Planet Report 2014. http://assets.worldwildlife.org/publications /723/ files/original/WWF-LPR2014 low_res.pdf?1413912230\&_ $\mathrm{ga}=2.124761673 .211640449 .1597681464-1028399813.1597681464$ (accessed on August 17 $7^{\text {th }}$ 2020).

Danijel Časni

\section{Ekologija u svjetlu Capetownskog iskaza o predanju}

Sažetak

Stvaranje planeta Zemlje zajedno s biljnim i životinjskim svijetom svoj je vrhunac imao u procesu stvaranja čovjeka na Božju sliku, a koju je čovjek kasnije 
uprljao grijehom. Rezultiralo je to udaljavanjem stvorenja od Stvoritelja i stvaranjem raznih kriza, pa tako i ekološke krize. Sukladno tomu, tema ekologije sve je aktualnija u našem vremenu, a mnogi predstavnici protestantskih i evanđeoskih kršćanskih crkava tijekom povijesti govorili su o važnosti ekologije. U našem vremenu ta se tematika dotakla na Trećem Lausannskom kongresu za evangelizaciju svijeta koji se održao u Capetownu 2010. Kako je skupu prisustvovao velik broj predstavnika evanđeoskih crkava diljem svijeta, izneseni stav u obliku dokumenta ujedno je i pogled na ekologiju iz prizme evanđeoskog kršćanstva.

Budući da se ljubav prema Bogu, među ostalim, izražava u ljubavi prema Božjem stvorenju, u ovome članku prvo se analizira odnos teologije i ekologije. Nakon toga razmatra se na koje bi načine biblijski zapis stvaranja trebao informirati i formirati odnos evanđeoskih kršćana prema Zemlji. Treći dio članka bavi se pitanjem „ekološkog otiska“ na razini svijeta te sagledava gdje se u svemu tome nalazi Hrvatska. Četvrti dio članka donosi pogled na ekologiju iz prizme protestantskih i evanđeoskih crkva, dok se u petom dijelu razmatraju izazovi današnjeg vremena i nude se dva smjera djelovanja: jedan je materijalističko-humanistički, a drugi je protestantsko-evanđeoski. U članku se zaključuje kako su kršćani, kao djeca Božja, pozvani vršiti volju Nebeskog Oca te biti primjerom i svjetlom u egocentričnom svijetu današnjice. Ekološke su krize u neposrednoj korelaciji s krizom morala, ali, jednako tako, sve aktivnosti koje se provode u svrhu očuvanja okoliša, a bez promjene čovjekove biti, k tomu posljedično i njegovih navika, ostvaruju samo kratkoročne rezultate bez temeljitih promjena. Jedino promjenom samoga čovjeka i njegovim pokajanjem, on može postati odgovoran u svome etičkom pristupu prema okolišu koji ga okružuje. 